\title{
Detection of infectious salmon anaemia virus (ISAV) by in situ hybridisation
}

\author{
A. Gregory* \\ Fisheries Research Services Marine Laboratory, PO Box 101, Victoria Road, Aberdeen AB11 9DB, Scotland, UK
}

\begin{abstract}
An in situ hybridisation method was developed to detect infectious salmon anaemia virus (ISAV) in fixed tissues from Atlantic salmon Salmo salar L. Three DNA probes detected ISAV in heart, liver, kidney, spleen, caeca, and mid-gut from infected farmed Atlantic salmon obtained from a natural outbreak of ISA. The strongest signals were obtained using Probe S8, from Segment 8 of ISAV. Hybridisation was most prominent in the endothelial cells of heart tissue. The probes reacted specifically with ISAV; no hybridisation was evident in uninfected tissues from Atlantic salmon. Importantly, the probes did not cross react with the pathogens IHNV (haematopoietic necrosis virus), IPNV (infectious pancreatic necrosis virus), SPDV (salmon pancreas disease virus) and VHSV (viral haemorrhagic septicemia virus).
\end{abstract}

KEY WORDS: Infectious salmon anaemia virus · ISAV · In situ hybridisation · DNA probes

Resale or republication not permitted without written consent of the publisher

\section{INTRODUCTION}

Infectious salmon anaemia virus (ISAV) is the aetiological agent of a severe disease that has led to significant losses in the salmon farming industry. First recognised in Norway in 1984, the disease has been diagnosed in Canada (Mullins et al. 1998, Bouchard et al. 1999, Lovely et al. 1999), Scotland (Bricknell et al. 1998, Rodger et al. 1998, Stagg et al. 1999) and the Faeroe Islands (Anonymous 2000). Typical pathological changes include severe anaemia, haemorrhagic liver necrosis and petechia of the viscera (Stagg et al. 1999). The causative agent has been identified as an orthomyxovirus-like enveloped virus with a genome comprised of 8 RNA segments (Mjaaland et al. 1997).

ISAV infection can, at present, be diagnosed using a variety of methods. At clinical levels, gross and histopathology are used (Evensen et al. 1991, Falk \& Dannevig 1995, Speilberg et al. 1995, Byrne et al. 1998). At sub-clinical levels the virus can be detected using virus isolation on salmon head kidney (SHK) cells (Dannevig et al. 1995), reverse-transcription polymerase chain reaction (RT-PCR) (Mjaaland et al. 1997, Blake et al. 1999, Bouchard et al. 1999, Rimstad et al. 1999), and immunofluorescent antibody testing (IFAT) (Mjaaland

*E-mail: gregorya@marlab.ac.uk et al. 1997, Blake et al. 1999, Bouchard et al. 1999, Rimstad et al. 1999). These sub-clinical diagnostic methods vary in their sensitivity and specificity. RT-PCR is generally thought to be the most sensitive method (Devold et al. 2000, Optiz et al. 2000), virus isolation is of intermediate sensitivity (Optiz et al. 2000), and IFAT is the least sensitive and most subjective method used (Optiz et al. 2000).

In situ hybridisation (ISH) is a technique by which target nucleic acid is detected in tissues, cells or chromosomes using nucleic acid probes (Leitch et al. 1994). It is a sensitive method that has been extensively used in medical virology for applications including elucidation of modes of viral replication, defining the mechanism of herpes virus latency in vivo and establishing a link between virus infections and carcinogenesis (Teo 1990). In recent years, it has been successfully developed for a variety of diseases of aquatic organisms including viruses from crustaceans (Bruce et al. 1993, Mari et al. 1993, 1995, 1998, Durand et al. 1996, Walton et al. 1999), shellfish (Le Roux et al. 1999, Cochennec et al. 2000, Kleeman \& Adlard 2000), and parasites from fishes (Antonio et al. 1998, Sanchez et al. 1999, Lee et al. 2000, Morris et al. 2000). The technique is particularly useful because it has the potential to reveal sites of infection within tissues at the cellular level, diagnose infection in sub-clinical cases, and dis- 
tinguish different strains of viruses. To date, there has only been 1 report of the use of ISH to detect a fish virus: Biering \& Bergh (1996) reported the detection of IPNV in Atlantic halibut (Hippoglossus hippoglossus L.), yolk-sac larvae.

The aim of this study was to develop an ISH protocol for the detection of ISAV in infected Atlantic salmon, Salmo salar. This would provide an important diagnostic tool to complement histological and molecular diagnostic methods. Importantly, it could be used as an epidemiological tool by screening archived samples to examine the temporal and geographical distribution of ISAV.

\section{MATERIALS AND METHODS}

Probe preparation. ISAV Isolate 390/98 was cultured in SHK cells according to the method of Dannevig et al. (1995). RNA was prepared according to the method described by Cunningham \& Snow (2000). An aliquot of $2 \mu \mathrm{g}$ RNA was used in each RT-PCR using MMLV-RT (Life Technologies) as described by Mjaaland et al. (1997). Three PCR products were produced from 3 different segments of the ISAV genome using the primers shown in Table 1. An $878 \mathrm{bp}$ region of Segment 8 (hereafter S8) of the ISAV genome was amplified as described by Cunningham \& Snow (2000). The amplification reaction for a $315 \mathrm{bp}$ region of Segment 2 (hereafter S2) was prepared according to the method described by Cunningham \& Snow (2000) and subjected to 35 cycles of $94^{\circ} \mathrm{C}$ for $1 \mathrm{~min}, 60^{\circ} \mathrm{C}$ for $1 \mathrm{~min}$ and $72^{\circ} \mathrm{C}$ for $1 \mathrm{~min}$ in a thermal cycler (Cyclogene, Techne). A 358 bp region of Segment 6 (hereafter S6) was amplified using identical conditions to those described for preparation of S2. Primers for the amplification of S6 were designed from sequence data described by Rimstad et al. (2001).

Following amplification, the products were subjected to electrophoresis in a $1.5 \%(\mathrm{w} / \mathrm{v})$ agarose gel and stained with ethidium bromide. The PCR products were purified using Wizard PCR preps (Promega) and cloned according to the manufacturer's instructions using the pGEMT easy vector system (Promega).

Probe labelling and quantification. The products S8, S2 and S6 were labelled by incorporation of Digoxigenin-11-dUTP (Roche) during PCR. The manufacturer's (Roche) instructions were used as a guide and conditions were optimised for these products. For each labelling reaction the following final concentrations of reagents were added to a $0.2 \mathrm{ml}$ reaction tube: $1 \times$ PCR buffer (Roche), $0.7 \times$ labeling mix (Roche), $0.3 \times$ dNTP solution (Roche) $28 \mathrm{pmol}$ of each forward and reverse primer described in Table 1, 2.6 Units enzyme mix (Roche), 100 pg plasmid template, and $\mathrm{dH}_{2} \mathrm{O}$ to a final volume of $50 \mu \mathrm{l}$. The reagents were mixed gently and overlaid with mineral oil, placed in a thermal cycler (Cyclogene, Techne) and subjected to the cycling conditions described above for each fragment. Following amplification, $10 \mu \mathrm{l}$ of product was analysed by gel electrophoresis using a $1 \%$ $(w / v)$ agarose gel stained with ethidium bromide. The remaining product was transferred to a new tube and quantified as described by the manufacturer (Roche).

Histology. Small pieces $\left(5 \mathrm{~mm}^{3}\right)$ of heart, liver, kidney, spleen, pancreas/caeca, mid-gut and 1 to 2 gill arches were placed in a tube containing $8 \%$ buffered formol saline at a 20:1 ratio (fixative to tissue volume) for a minimum of $15 \mathrm{~h}$ and a maximum of $3 \mathrm{~d}$. Prior to embedding, gill samples were decalcified using a modified Perenyi's decalcifying fluid (Bruno \& Poppe 1996). Samples from 5 farmed fish previously diagnosed positive for ISAV by histology, virology and PCR from natural outbreaks of ISA in Scotland were selected for ISH. Samples from a further five fish (3 of which pre-dated the first outbreak of ISA in Scotland) from locations where no ISA occurred which were negative by histology were also selected for testing. In addition, tissues from fish infected with the pathogens infectious pancreatic necrosis virus (IPNV) infectious haematopoietic necrosis virus (IHNV), salmon pancreas disease virus (SPDV) and viral haemorrhagic septicemia virus (VHSV), previously diagnosed by histology, were selected for ISH. Sections $(5 \mu \mathrm{m})$ were cut and placed onto Polysine ${ }^{\circledR}$ slides (Merck) in preparation for ISH.

In situ hybridisation. Samples were de-waxed in Clearene (Merck) for 10 min and hydrated through an

Table 1. Probe data showing primer sequences used to generate each ISAV probe. \% GC content: percentage of cytosine and guanine nucleotides in each DNA sequence; $T\left({ }^{\circ} \mathrm{C}\right)$ : melting temperature of each probe (both these parameters are important factors in determining the stability of nucleic acid duplexes in the hybridisation reaction); For: forward; Rev: reverse

\begin{tabular}{|llrc|}
\hline $\begin{array}{l}\text { Probe no. } \\
\text { (length) }\end{array}$ & Primer sequences & $\begin{array}{r}\text { \% GC } \\
\text { content }\end{array}$ & $\begin{array}{c}T \\
\left({ }^{\circ} \mathrm{C}\right)\end{array}$ \\
\hline $\begin{array}{l}\text { S8 } \\
(878 \mathrm{bp})\end{array}$ & $\begin{array}{l}\text { For }=5^{\prime} \text { GGCTATCTACCATGAACGAATC 3' } \\
\text { Rev }=5^{\prime} \text { TCTTTTGTATAATGATCAAGTACAC 3' }\end{array}$ & 43.5 & 63.5 \\
S2 & For = 5'GAGAGCATGTGCCCAGAAGTGAT 3' & 45.9 & 65.6 \\
$(315 \mathrm{bp})$ & $\begin{array}{l}\text { Rev }=\text { 5'CGTAGATGCCGTTGTAAAAGC3' }^{\prime} \\
\text { S6 }\end{array}$ & & \\
$(358 \mathrm{bp})$ & $\begin{array}{l}\text { For }=5^{\prime} \text { 'ATGACTGCACTGACGGACCT 3' } \\
\text { Rev }=5^{\prime} \text { 'GGTTCCCTCACTTCAAAGGTGTCTGA 3' }\end{array}$ & 47.9 & 65.7 \\
\hline
\end{tabular}


alcohol series. Slides were rinsed 3 times in DEPCtreated $\mathrm{H}_{2} \mathrm{O}$ and incubated in PBS (phosphatebuffered saline) for $10 \mathrm{~min}$ at room temperature. In a humid chamber, $500 \mu \mathrm{l}$ of proteinase $\mathrm{K}$ was added to each slide (final concentration $=10 \mu \mathrm{g} \mathrm{ml}{ }^{-1}$ ). Slides were covered with a hybri-slip (Sigma) and incubated at $37^{\circ} \mathrm{C}$ for $15 \mathrm{~min}$. Proteinase $\mathrm{K}$ was drained off and the slides were post-fixed in cold $0.4 \%$ formaldehyde in DEPC-treated $\mathrm{H}_{2} \mathrm{O}$ for $5 \mathrm{~min}$ and washed in $2 \times$ saline sodium citrate (SSC) at room temperature for 5 min. In a humid chamber, $500 \mu$ l of pre-warmed $\left(42^{\circ} \mathrm{C}\right)$ hybridisation buffer was added per slide $(50 \%$ fomamide, $4 \times \mathrm{SSC}, 1 \times$ Denhardt's, $0.2 \mathrm{mg} \mathrm{ml}^{-1}$ yeast RNA, $0.5 \mathrm{mg} \mathrm{ml}^{-1}$ salmon sperm DNA, 5.0\% dextran sulphate, DEPC-treated $\mathrm{H}_{2} \mathrm{O}$ final conc.) and incubated at $42^{\circ} \mathrm{C}$ for $30 \mathrm{~min}$. The probes were denatured by boiling for $10 \mathrm{~min}$, then placing immediately on ice. Probe (S8, S6 or S2) was added to the hybridisation buffer (as above) at a final concentration of $20 \mathrm{ng} \mathrm{ml}^{-1}$. $250 \mu \mathrm{l}$ of hybridisation buffer containing the probe was placed on each slide, covered with a hybri-slip and incubated overnight in a humid chamber at $42^{\circ} \mathrm{C}$.

Following hybridisation, slides were washed twice for 15 min each in $2 \times \mathrm{SSC}$ at room temperature, twice in $1 \times \mathrm{SSC}$ for $5 \mathrm{~min}$ each at $37^{\circ} \mathrm{C}$ and twice in $0.5 \times \mathrm{SSC}$ for $5 \mathrm{~min}$ each at $37^{\circ} \mathrm{C}$. Detection was performed using the DIG (digoxigenin) nucleic acid detection kit according to manufacturer's (Roche) instructions. The anti-DIG-AP antibody conjugate was diluted to a $1: 1000$ ratio and the colour reaction was allowed to proceed overnight. Slides were rinsed in water 3 times, counterstained with $0.5 \%$ Bismarck brown in $\mathrm{dH}_{2} \mathrm{O}$ and mounted using glycerol-gelatin (Sigma).

\section{RESULTS}

Positive hybridisation signals were observed in all 5 ISA-infected fish tested with all 3 probes. Hybridisation was evident in heart, liver, kidney, spleen, cacea and mid-gut of the infected fish but was absent from gill using Probes S8 and S6, and mid-gut and gill with Probe S2. The intensity of the signal varied between the probes: S8 produced the strongest signals (Fig. 1, Table 2), S6 intermediate intensity signals (data not shown) and S2 the weakest signals (Fig. 1). The intensity of the signal also varied between organs: the strongest signals with all probes were observed in the heart (Fig. 1), signals from the liver (Fig. 2), kidney and spleen were of intermediate intensity, and those from the gut and caeca produced the lowest-intensity signals (Table 2). Hybridisation was not evident in any of the negative fish tested. Importantly, the probes did not hybridise to tissues infected with IPNV, SPKD, IHNV or VHSV (Table 2).
Table 2. Summary of in situ hybridisation results from tissues infected with different viruses tested using S8 probe. Viruses tested were infectious salmon anaemia virus (ISAV), infectious haematopoietic necrosis virus (IHNV), infectious pancreatic necrosis virus (IPNV), salmon pancreas disease virus (SPDV) and viral haemorrhagic septicemia virus (VHSV). +++: high intensity signal ${ }_{i}++$ : medium intensity; + : low intensity; -: no signal observed

\begin{tabular}{|llllll|}
\hline Tissue type & ISAV & IHNV & IPNV & SPDV & VHSV \\
\hline Heart & +++ & - & - & - & - \\
Liver & ++ & - & - & - & - \\
Kidney & ++ & - & - & - & - \\
Spleen & ++ & - & - & - & - \\
Caeca & + & - & - & - & - \\
Mid-gut & + & - & - & - & - \\
Gill & - & - & - & - & - \\
\hline
\end{tabular}

Hybridisation occurred at distinct locations within each positive tissue. In the heart, positive signals were present in endothelial cells (Fig. 1). In the liver and spleen, hybridisation was apparent in the endothelial lining of the blood vessels (Fig. 2). Positive signals in the kidney were present in the haematopoietic tissues and those in the cacea and mid-gut in the lamina propria (data not shown).

\section{DISCUSSION}

This paper reports the development of DNA probes that can detect ISAV in formalin-fixed heart, liver, kidney, spleen, caeca and mid-gut from infected farmed Atlantic salmon, Salmo salar, obtained from a natural outbreak of ISA. The probes reacted specifically with ISAV; no hybridisation was evident in uninfected tissues from Atlantic salmon. Importantly, the probes did not cross-react with the notifiable pathogens IHNV, IPNV, and VHSV, nor with SPDV. It was not possible to test the probes on a virus more closely related to ISAV since the only reports of another orthomxyovirus-like virus from fish are from the European eel Anguilla anguilla with stomatopapilloma (Wolf \& Quimby 1972, Nagabayashi \& Wolf 1979, Ahne \& Thomsen 1985). This eel virus exhibits the general characteristics of orthomxyoviruses, although the viral RNA has not been characterised (Nagabayashi \& Wolf 1979).

DNA probes from Segments 8, 6 and 2 of ISAV all produced positive signals; however, the intensity of the signal varied between probes. The nature and stability of the probes or variation in the copy number of the target genes may explain the variation in signal intensity. There are a number of factors that are important in determining the stability of a nucleic acid hybrid, including probe length, GC (cytosine and guanine nucleotides) content, hybridisation buffer and melting 

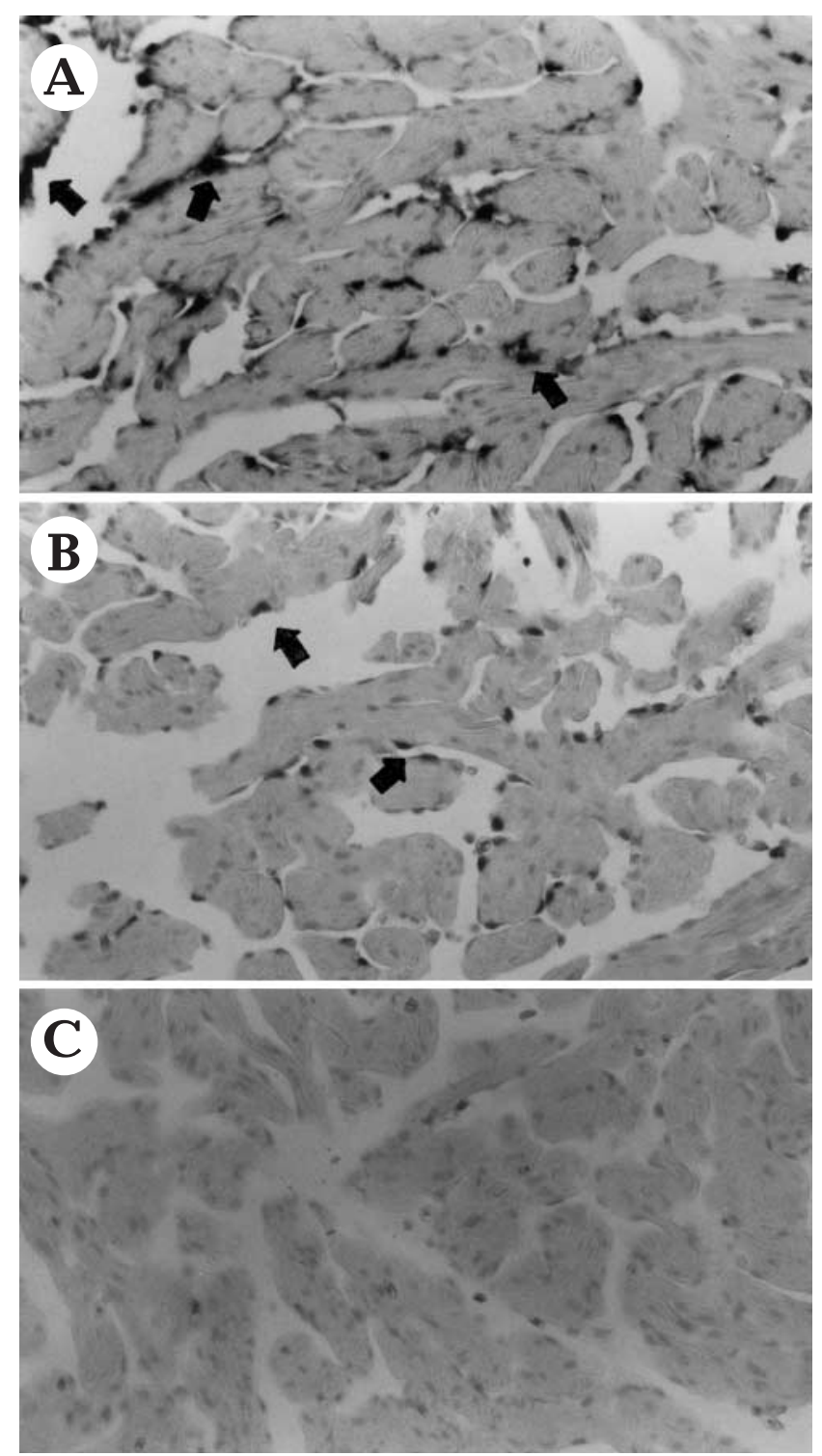

Fig. 1. (A,B) In situ hybridisation (ISH) results from serial sections of heart from an ISA-infected Atlantic salmon Salmo salar using Probe S8 (A) and Probe S2 (B); positive hybridisation signals are evident in endothelial cells (arrows). (C) Negative control; no probe was used. (All magnifications $\times 150$ )

temperature (Leitch et al. 1994). In general, short probes with low GC contents and low melting temperatures are less stable than longer ones with higher GC content and melting temperature (Leitch et al. 1994). In the present study, the shortest probe, S2, did produce the lowest signals. However, S8 and S6 only differed in length, suggesting that variation in the signal was not only due to the nature of the probe and the hybridisation conditions used. All 3 probes were constructed from different segments of the ISAV genome. Probe S8 was constructed from the segment which encodes non- structural proteins (Mjaaland et al. 1997), S2 from that encoding the polymerase gene (Krossøy et al. 1999), and S6 from that encoding the haemagglutinin gene (Rimstad et al. 2001). To date very little is known about these genes and their expression during replication. However, the replication of influenza viruses, which are also members of the orthomyxoviridae, has been extensively studied (Lamb \& Krug 1996). In an influenza virus infection there is preferential synthesis of some viral RNAs at different stages of infection; specifically, the non-structural proteins and the nucleoproteins are synthesised in large quantities early in infection (Lamb \& Krug 1996). The differences in positive signal intensities with Probes S2, S6 and S8 may reflect a variation in expression of each gene. Clearly, the use of different DNA probes for ISAV may have an important use in further understanding the replicative cycle of ISAV.

In this study, the strongest signals with all probes were obtained from the heart tissue. The signals were specifically located within the endothelial cells of this tissue. This was expected, since Hovland et al. (1994)
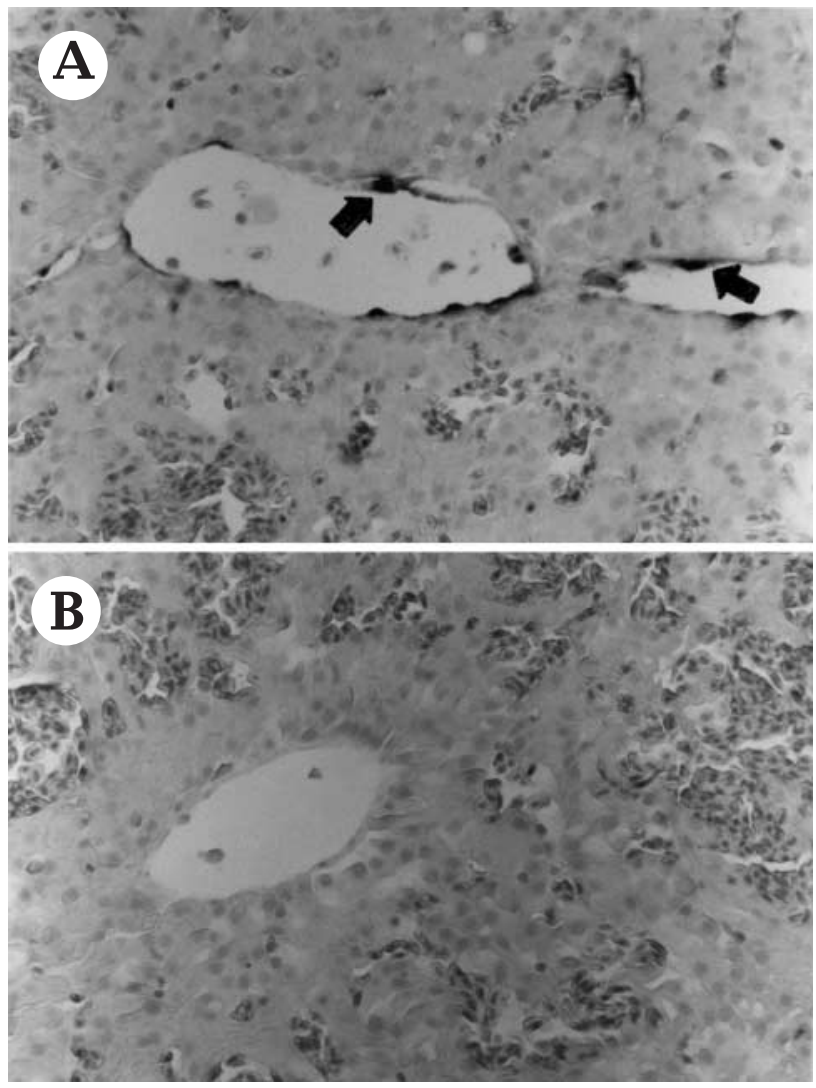

Fig. 2. In situ hybridisation results from serial sections of liver from an ISA-infected Atlantic salmon Salmo salar using Probe S8 (A), positive hybridisation signals are evident in endothelial cell lining of the veins shown (arrows). (B) negative control; no probe was used. (Both magnifications $\times 200$ ) 
reported observing virus particles most frequently in the heart, budding from endothelial cells. In addition, endothelial cells have been recognised as the main tissue for ISAV replication (Nylund et al. 1995, Koren \& Nylund 1997). The weakest signals were observed in the pyloric caeca and gut. Positive signals were observed in the lamina propria of the pyloric caeca. This corresponds to the morphological findings of Evensen et al. (1991), who reported congestion and sometimes diffuse bleeding in the lamina propria of ISA-infected salmon. The kidneys of ISA-infected fish exhibit congestion of the sinusoids and individual haematopoietic cells show degeneration and necrosis (Evensen et al. 1991). The most prominent hybridisation signals in the kidney were found in the haematopoietic and interstitial tissues, which correspond to the areas in which histopathological changes occur.

Liver and spleen signals were lower than expected, given the major pathological changes that can occur during ISAV infection (Evensen et al. 1991). Interestingly, Evensen et al. (1991) reported that blood-filled cavities in the liver did not seem to have any endothelial cell lining and that swollen and degenerate endothelial cells were found in small and mediumsized blood vessels. In the present study, the only positive signals from the liver and spleen were found in medium-sized blood vessels, and may represent the degenerate endothelial cells reported by Evensen et al. (1991). It is possible that low signals elsewhere in the liver were due to degradation of the endothelial cell lining. An alternative possibility is that the liver and spleen may require different conditions for hybridisation than the heart. In this study, all organs to be tested from each fish were embedded in one wax block, sectioned and subjected to the same procedure. It is likely that optimal conditions will vary between organs because some will be more prone to degradation. The Proteinase $\mathrm{K}$ concentration of $10 \mu \mathrm{g} \mathrm{ml}^{-1}$ used in this method is lower than that used in other studies (Mari et al. 1995, Biering \& Bergh 1996), because it limited degradation of the wide selection of tissue types in each block. Organs could be processed separately to determine whether different concentrations are required to enhance signals obtained from the liver and spleen.

In this study, no positive hybridisation was observed in the gill tissue. This result was not expected, since the gills contain numerous endothelial cells on each lamella (Yasutake \& Wales 1983), and Nylund et al. (1995) reported budding of the virus from the surface of endothelial cells in all tissues tested. In addition, Rimstad et al. (1999) detected ISAV by RT-PCR in gill samples of experimentally infected salmon up to $40 \mathrm{~d}$ post-challenge. Since the gills were the only organs subjected to decalcification in the present study, it is likely that RNA within gill tissues was degraded due to hydrolysis in the extremely acidic conditions used for decalcification. Clearly, if gills are to be used in the ISH process then decalcification would have to be avoided to preserve viral RNA; however, this is likely to comprise the ability to section gill tissue effectively.

The successful development of this ISH procedure is important to future investigations of ISAV. It is another diagnostic tool that can be used alongside others, particularly histology, to confirm cases with suspect pathology. It may also prove to be a useful epidemiological tool because it can be used to screen archived samples. Such studies will provide important information on the origins and geographical distributions of ISAV.

Acknowledgements. The author would like to thank Dr. D. W. Bruno for his technical advice and review of this manuscript. The assistance of the histopathology group from FRS Marine Laboratory, Aberdeen, is gratefully acknowledged.

\section{LITERATURE CITED}

Ahne W, Thomsen I (1985) The existence of three different viral agents in a tumour bearing European eel (Anguilla anguilla). Zentbl VetMed Reihe B 32:228-235

Anonymous (2000) ISA hits the Faroes. Fish Farming Int $27(5): 47$

Antonio DB, Andree KB, McDowell TS, Hedrick RP (1998) Detection of Myxobolus cerebralis in rainbow trout and oligochaetae tissues by using a nonradioactive in situ hybridisation (ISH) protocol. J Aquat Anim Health 10:338-347

Biering E, Bergh Ø (1996) Experimental infection of Atlantic halibut, Hippoglossus hippoglossus L., yolk-sac larvae with infectious pancreatic necrosis virus: detection of virus by immunohistochemistry and in situ hybridisation. J Fish Dis 19:405-413

Blake S, Bouchard D, Keleher W, Opitz M, Nicholson BL (1999) Genomic relationships of the North American isolate of infectious salmon anemia virus (ISAV) to the Norwegian strain of ISAV. Dis Aquat Org 35:139-144

Bouchard D, Keleher W, Opitz HM, Blake S, Edwards KC Nicholson BL (1999) Isolation of infectious salmon anemia virus (ISAV) from Atlantic salmon in New Brunswick, Canada. Dis Aquat Org 35:131-137

Bricknell IR, Bruno DW, Cunningham CO, Hastings TS, McVicar AH, Munro PD, Raynard RS, Stagg RM (1998) Report on the first occurrence of infectious salmon anemia (ISA) in Atlantic salmon (Salmo salar) in Scotland, United Kingdom. In: Proc 3rd Int Symp Aquatic Animal Health, Baltimore, 30th August-3rd September 1998. APC Press, Baltimore, MD

Bruce LD, Redman RM, Lightner DV, Bonami, JR (1993) Application of gene probes to detect a penaeid shrimp baculovirus in fixed tissue using in situ hybridisation. Dis Aquat Org 17:215-221

Bruno DW, Poppe TT (1996) A colour atlas of salmonid diseases. Academic Press, London

Byrne PJ, MacPhee DD, Ostland VE, Johnson G, Ferguson HW (1998) Haemorrhagic kidney syndrome of Atlantic Salmon, Salmo salar L. J Fish Dis 21:81-91 
Cochennec N, Le Roux F, Berthe F, Gerard A (2000) Detection of Bonamia ostreae based on small subunit ribosomal probe. J Invertebr Pathol 76:26-32

Cunningham CO, Snow M (2000) Genetic analysis of infectious salmon anaemia virus (ISAV) from Scotland. Dis Aquat Org 41:1-8

Dannevig BH, Falk K, Namork E (1995) Isolation of the causal virus of infectious salmon anemia (ISA) in a long-term cell line from Atlantic salmon head kidney. J Gen Virol 76:1353-1359

Devold M, Krossøy B, Aspehaug V, Nylund A (2000) Use of RT-PCR for diagnosis of infectious salmon anaemia virus (ISAV) in carrier sea trout Salmo trutta after experimental infection. Dis Aquat Org 40:9-18

Durand S, Lightner DV, Nunan LM, Redman RM, Mari J, Bonami JR (1996) Application of gene probes as diagnostic tools for white spot baculovirus (WSBV). Dis Aquat Org 27:59-66

Evensen $\varnothing$, Thorud KE, Olsen YA (1991) A morphological study of the gross and light microscopic lesions of infectious salmon anaemia in Atlantic salmon (Salmo salar). Res Vet Sci 51:215-222

Falk K, Dannevig BH (1995) Demonstration of a protective immune response in infectious salmon anaemia (ISA)-infected Atlantic salmon Salmo salar. Dis Aquat Org 21:1-5

Hovland T, Nylund A, Watanabe K, Endresen C (1994) Observations of infectious salmon anaemia virus in Atlantic salmon, Salmo salar L. J Fish Dis 17:291-296

Kleeman SN, Adlard RD (2000) Molecular detection of Marteilia sydneyi, pathogen of Sydney rock oysters. Dis Aquat Org 40:137-146

Koren CWR, Nylund A (1997) Morphology and morphogenesis of infectious salmon anaemia virus replicating in the endothelium of Atlantic salmon Salmo salar. Dis Aquat Org 29:99-109

Krossøy B, Hordvik I, Nilsen F, Nylund, A, Endresen C (1999) The putative polymerase sequence of infectious salmon anemia virus suggests a new genus within the Orthomyxoviridae. J Virol 73:2136-2142

Lamb RA, Krug RM (1996) Orthomyxoviridae: the viruses and their replication. In: Fields B, Knipe DM, Howley PM et al. (eds) Fields virology, Vol 1. Lippencott-Raven, Philadelphia, p 1353-1395

Lee SJ, Yokoyama H, Ogawa K, Wakabayashi, H (2000) In situ hybridisation for detection of the microsporidian parasite Glugea plecoglossi by using rainbow trout as an experimental infection model. Fish Pathol 35:79-84

Leitch, AR, Schwarzacher T, Jackson D, Leitch IJ (1994) In situ hybridisation: a practical guide. BIOS Scientific in association with the Royal Microscopical Society, Oxford

Le Roux F, Audemard C, Barnaud A, Berthe F (1999) DNA probes as potential tools for the detection of Marteilia refringens. Mar Biotechnol 1:588-597

Lovely JE, Dannevig BH, Falk K, Hutchin L, MacKinnon AM, Melville KL, Rimstad E, Griffiths SG (1999) First indentification of infectious salmon anaemia virus in North America with haemorrhagic kidney syndrome. Dis Aquat Org 35:145-148

Mari J, Bonami JR, Lightner DV (1993) Partial cloning of the genome of infectious hypodermal and haematopoietic necrosis, an unusual parvovirus pathogenic for penaeid shrimps: diagnosis of the disease using a specific probe. J Gen Virol 74:2637-2643

Mari J, Lightner DV, Poulos BT, Bonami JR (1995) Partial cloning of the genome of an unusual shrimp parvovirus (HPV): use of gene probes in disease diagnosis. Dis Aquat
Org 22:129-134

Mari J, Bonami JR, Lightner DV (1998) Taura syndrome of penaeid shrimp: cloning of viral genome fragments and development of specific gene probes. Dis Aquat Org 33:11-17

Mjaaland S, Rimstad E, Falk K, Dannevig BH (1997) Genomic characterization of the virus causing infectious salmon anemia in Atlantic salmon (Salmo salar L.): an orthomyxolike virus in a teleost. J Virol 71:7681-7686

Morris DJ, Adams A, Richards RH (2000) In situ hybridisation identifies the gill as a portal of entry for PKX (phylum Mxyozoa), the causative agent of proliferative kidney disease in salmonids. Parasitol Res 86:950-956

Mullins JE, Groman D, Wadowska D (1998) Infectious salmon anaemia in salt water Atlantic salmon (Salmo salar L.) in New Brunswick, Canada. Bull Eur Assoc Fish Pathol 18:110-114

Nagabayashi T, Wolf K (1979) Characterisation of EV-2, a virus isolated from European eels (Anguilla anguilla) with stomatopapilloma. J Virol 30:358-364

Nylund A, Hovland T, Watanabe K, Endresen C (1995) Presence of infectious salmon anaemia virus (ISAV) in tissues of Atlantic salmon, Salmo salar L., collected during three separate outbreaks of the disease. J Fish Dis 18:135-145

Optiz HM, Bouchard D, Anderson E, Blake S, Nicholson B, Keleher W (2000) A comparison of methods for the detection of experimentally induced subclinical infectious salmon anaemia in Atlantic Salmon. Bull Eur Assoc Fish Pathol 20:12-22

Rimstad E, Falk K, Mikalsen AB, Teig A (1999) Time course distribution of infectious salmon anaemia virus in experimentally infected Atlantic salmon Salmo salar. Dis Aquat Org 36:107-112

Rimstad E, Mjaaland S, Snow M, Mikalsen AB, Cunningham CO (2001) Characterisation of the infectious salmon anemia virus genomic segment that encodes the putative hemagglutinin. J Virol 75:5352-5356

Rodger HD, Turnbull T, Muir F, Millar S, Richards RH (1998) Infectious salmon anaemia (ISA) in the United Kingdom. Bull Eur Assoc Fish Pathol 18:115-116

Sanchez JG, Speare DJ, Markham RJF (1999) Nonisotopic detection of Loma salmonae (Microspora) in rainbow trout (Oncorhynchus mykiss) gills by in situ hybridisation. Vet Pathol 36:610-612

Speilberg L, Evensen Ø, Dannevig BH (1995) A sequential study of light and electron microscopic liver lesions of infectious anaemia in Atlantic salmon (Salmo salar L.). Vet Pathol 32:466-478

Stagg R, Bruno D, Cunningham CO, Hastings T, Bricknell I (1999) Focus on infectious salmon anaemia: epizootiology and pathology. State Vet J 9:1-5

Teo CJ (1990) In situ hybridisation in virology. In: Polak JM McGee J (eds) In situ hybridisation. Oxford University Press, New York, p 125-147

Walton A, Montanie H, Arcier JM, Smith VJ, Bonami JR (1999) Construction of a gene probe for detection of $P$ virus (reoviridae) in a marine decapod. J Virol Methods 81(2):183-192

Wolf K, Quimby MC (1972) Virology of eel stomatopapilloma. Progress in sport fishery research 1970, Resource publication 106. United States Department of the Interior, Fish \& Wildlife Services, Washington, DC

Yasutake WT, Wales JH (1983) Microscopic anatomy of salmonids: an atlas. Resource publication 150. United States Department of the Interior Fish \& Wildlife Services, Washington, DC

Submitted: August 22, 2001; Accepted: February 17, 2002

Proofs received from author(s): June 24, 2002 